'It is not sensational presentation of the romantic aspects of medicine, though the romance is there for a sympathetic eye to discern. It is not a history of the achievements of medical science, though these form its background. It is not a popular medical encyclopaedia or even a domestic medical manual. No one will learn from it how to treat illness, though he will learn how illness is treated' (our italics).

We doubt whether any review can adequately convey the charm and the value of this work. Of their reality we are certain, and we congratulate Mr. Hollis on his achievement and his publishers on their vision and courage in this fine educational experiment.

Q.F.C.

\section{PULMONARY TUBERCULOSIS}

By R. Y. KeERS, M.D., F.R.C.P., F.R.F.P.S., F.R.S.E., and B. G. RIGDEN, M.R.C.S., L.R.C.P. 3rd Edition. Pp. xvi +324 , illustrated. Edinburgh: E. \& S. Livingstone, Ltd. 1953. 245.

This is not a symposium on pulmonary tuberculosis, it is a small, short, yet perfectly adequate, survey of the clinical problems and the treatment of this disease. It includes also chapters on bacteriology, pathology and some sound words on the factors influencing the patient's resistance to the tubercle bacillus. The place of each of the various forms of treatment including collapse therapy and resection is clearly stated and a nice balance maintained throughout this part of the book. It can be recommended for the undergraduate student as it is just this sized volume which will meet his needs. The general practitioner also will find it of very great value.

L.L.B.

\section{MONOGRAPHS OF THE PHYSIOLOGICAL SOCIETY}

No. I. Sympathetic Control of Human Blood Vessels

By H. BarCrofT, M.A., M.D., M.R.C.P., and H. J. C. Swan, Ph.D., M.B., B.S., M.R.C.P. Pp. vii +165 , illustrated. London: Edward Arnold \& Co. 1953. I8s.

In this valuable monograph the authors have assembled their observations and conclusions drawn from investigations in a field of clinical research which is of much more than academic interest. No animal experiment could have yielded the type of information which is presented here. Direct evidence of the nervous mechanisms of vascular control in man is presented, with examples of the changes produced in the muscle and skin of the extremities by such factors as fainting, the intravenous infusion of adrenalin, exercise and sympathetic denervation. The functional disturbance produced by a phaechromocytoma is explained and a rational basis for diagnosis is put forward. A useful chapter on plethysmography is included.

The book is filled with information which equally concerns the physiologist, physician or surgeon.

H.H.G.E.

\section{ROSE AND CARLESS' MANUAL OF SURGERY Vols. I and 2}

Edited by Sir Cecil Wakeley, Bt., K.B.E., C.B. 18th Edition. Pp. xii +746 and pp. viii +660 , with 1,025 illustrations, 18 in colour. London: Baillière, Tindall and Cox. 1952. 63s. the set.

This is certainly a new Rose and Carless. It has been extensively revised and many of the sections have been rewritten, a large number of them by well known authorities. It is very pleasing to see so much prominence given to fluid and electrolyte therapy and there are excellent chapters on otorhinolaryngology, plastic surgery and burns. As, however, with all textbooks written by a number of contributors, balance is not entirely satisfactory as exemplified in this case by an unusually long and complicated chapter on blood grouping. Whilst the book is up to date in nearly all its parts it is felt that there are one or two exceptions. No mention, for instance, is made of the operation of rectosigmoidectomy as a treatment for Hirschspring's disease. The first operation described for duodenal ulceration is gastro-enterostomy; it is felt that in a textbook for students partial gastrectomy should be given pride of place. Vagotomy alone is rightly dismissed in the treatment of this condition but the operation of vagotomy combined with a gastric decompression such as pyloroplasty or gastrojejunostomy ought to be discussed in this context.

This book is very long. In this way it contrasts with some of the other standard textbooks and its appeal will be to the student who prefers such a type of writing. This in no way implies that the work will not become popular.

D.L.B.F.

\section{THE MANAGEMENT OF ABDOMINAL OPERATIONS}

Edited by Rodney Maingot, F.R.C.S. Pp. xvi + 1,256, with $53^{8}$ illustrations. London: H. K. Lewis \& Co., Ltd. 1953. I20s.

Mr. Rodney Maingot's reputation as a surgical writer and editor is such that any new work appearing under his name excites feelings of the liveliest anticipation. These are further increased when it is seen that among his 33 contributors are many distinguished names in British medicine, such as Gordon Gordon-Taylor, Cecil Wakeley, L. J. Witts, Avery Jones, Ian Aird and Norman Tanner. It may be said at once that the book lives up to these expectations. Its title would imply a work devoted essentially to pre- and post-operative care, and approximately half the chapters do deal with general considerations of this kind. Mr. Maingot 